\title{
Species richness and diversity of Vespidae (Insecta: Hymenoptera) of Swat Khyber Pakhtunkhwa Pakistan
}

\author{
Muhammad Rasool $^{\mathrm{a}, \mathrm{b}, *}$, Muhammad Zahid ${ }^{\mathrm{a}}$, Khalid Khan ${ }^{\mathrm{a}}$, Muhammad Ismail Khan ${ }^{\mathrm{a}}$, \\ Qadeem Khan $^{\mathrm{a}, \mathrm{c}}$, Sahibzada Muhammad Jawad ${ }^{\mathrm{a}}$, Riaz Ahmad ${ }^{\mathrm{a}}$, Muhammad Sajid ${ }^{\mathrm{a}}$, Ikramullah $^{\mathrm{a}}$, \\ Mujeeb Ahmad ${ }^{\mathrm{a}}$ \\ a Department of Zoology, Islamia College University, Khyber Pakhtunkhwa, Pakistan \\ b Department of Zoology, Govt: Degree College, Kabal Swat, Pakistan \\ c Department of Zoology, Govt: Postgraduate College, Dargai, Pakistan
}

*Corresponding author, e-mail: imrasool72@yahoo.com

Received 20 Mar 2018

Accepted 21 Sep 2018

\begin{abstract}
Keeping in view the agricultural importance, Vespidae is an important family of the order Hymenoptera (Insecta). The objective of the study was to find out the number of species of the family and to mark the distribution of the species of the family Vespidae in various locations of the study area. The wasps were collected with the help of hand net through active search, killed with insecticide and preserved in insect boxes having naphthalene balls as preservatives. Species richness were calculated using Margalef and Menhinick indices while species diversity was calculated using Simpson diversity index. The most abundant subfamily was Polistinae with $65 \%$ abundance while the least abundant was the Eumeninae with $2 \%$ abundance. However, the most diverse and species rich subfamily is Eumeninae with a Simpson (1-D) value of 0.803, Menhinick and Margalef indices values of 1.540 and 2.543, respectively. Among the seven tehsils, Kabal is the most species rich and diverse having Margalef value 2.408, Menhinick Value 0.514 and Simpson (1-D) value 0.777 while Bahrain is the least species rich and having no diversity. The Margalef, Menhinick and Simpson (1-D) values for tehsil Bahrain are 0, 0.333, and 0, respectively. The Polistinae is the dominant subfamily in the area and can be used as biocontrol agent for various pests of agricultural importance.
\end{abstract}

KEYWORDS: Polistinae, Vespinae, Eumeninae, diversity indices, solitary wasps

\section{INTRODUCTION}

The Vespidae is a large and diverse family of the order Hymenoptera (Arthropoda: Insecta) including nearly 5000 species of wasps ${ }^{1}$. It is a cosmopolitan and predominantly tropical family ${ }^{2}$. Adult wasps are predominantly black or brown in colour but often may have yellow or white markings on the body. The subfamilies Polistinae and Vespinae contain the highly eusocial species while solitary species are included in the subfamilies Eumeninae, Eupragiinae and Masarinae ${ }^{3}$. The subfamily Eumeninae, also known as mason or potter wasp, is the most diverse and species rich with approximately 205 genera and 3743 species $^{4}$. The second largest subfamily is the Polistinae having 1100 species in total, and is the second most diverse subfamily. The subfamily Vespinae contains 67 known species under four genera ${ }^{5}$. Wasps perform valuable services in the ecosystem, though most people think of them as pests, they prey on various arthropods pests like caterpillars, spiders, bugs and flies and hence control their populations ${ }^{6}$. The wasps also help in cross pollination during their visits to flower and to obtain nectar. In some countries like Japan, the larvae and pupae are used as food and considered as a good source of protein. Hitherto, a stinging at their ovipositor poses a great threat to humans. Stinging is an excellent defence in wasp colonies against predators and other possible dangers ${ }^{7}$. The stings are dangerous, painful and even fatal if it causes an anaphylactic allergic reactions ${ }^{8}$.

The members of the family Vespidae like other insects needs to be identified and grouped in accordance with their environment, predator, prey, and climate $^{9}$. This will help obtain information about the habitat and niche of the species ${ }^{10}$ and its use as a predator, scavenger or pollinator ${ }^{11}$. The use of various statistical methods in ecology is to find out the asymptotic number of species not detected in the area ${ }^{11}$. The species richness estimates are based on assumptions that the observed species number is less than the actual number of species present 
in the area ${ }^{12}$. The main purpose of the study was to find out species richness, distribution, diversity and species evenness of Vespidae. Based on the information obtained from the study, various species of the family Vespidae can be used as pollinators of agriculturally important crops or predators of important crop pests.

\section{MATERIALS AND METHODS}

\section{Study area}

The valley of Swat is situated in the north of Khyber Pakhtunkhwa, $35^{\circ}$ North latitude and $72^{\circ}$ and $30^{\circ}$ East longitude, enclosed by the sky-high mountains ${ }^{13}$. Chitral and Gilgit are situated in the north, Dir in the west, and Mardan in the south, while Indus separates it from Hazara in the east. On the basis of Physical Features, Swat is divided into two physical regions: Mountainous Ranges and Plains. Swat is divided into seven tehsils: Babuzai, Barikot, Kabal, Matta, Charbagh, Khwazakhela and Bahrain. Each tehsil is divided into certain number of union council ${ }^{14}$.

\section{Collection}

The seven locations (Tehsils) were visited once a month from April 2014 to November 2016 for the collection of wasps. The wasps were captured by active searching with the help of hand net. After catching, the wasps specimens were killed with the help of insecticide spray (Mortein) in the net. The specimens were then stretched on setting boards and labelled with full data such as date and locality of the specimen with altitude, latitude and longitude and pinned in the insect box. Phenolphthalein balls were placed in the boxes as preservative.

\section{Identification}

The specimens were examined with the help of Stereoscope (Labomet CZM4-4X, Japan) and identified up to species level by running them through latest available literature, Vespine wasps of the world ${ }^{5}$; new records of vespid wasps from Yemen with synonymy in Belonogaster (Hymenoptera: Vespidae: Polistinae and Eumeninae) ${ }^{15}$; a catalogue of the Eumeninae (Hymenoptera: Vespidae) of the Ethiopian region ${ }^{16}$; catalogue of the vespid wasps of $\operatorname{Iran}^{17}$.

\section{Statistical Analysis}

The relative abundance $\left(R_{\mathrm{A}}\right)$ of the species was calculated by using the formula ${ }^{12}, R_{\mathrm{A}}=n_{i} / N$, where $n_{i}$ is the number of individuals in the $i$ th species and $N$ is the total number of individuals in the sample or sampling area.
The specie richness $R$ was calculated by using Margalef's index ${ }^{18}$ and Menhinick's index ${ }^{19}$. The forms of Margalef's and Menhenick's are $R=(S-$ 1)/ $\ln (N)$ and $R=S / \sqrt{N}$, repesctively, where $S$ is the number of species.

The diversity $D$ was calculated by Simpson diversity index ${ }^{20}, D=\sum n_{i}\left(n_{i}-1\right) / N(N-1)$, as $D$ measures dominance, so the higher value of $D$ lesser value of the diversity. In this index, 0 means infinite diversity and 1 represents no diversity, therefore, Simpson index of diversity $1-D$ was used. In this case, increase in value of Simpson (1-D) means increase in diversity.

\section{RESULTS}

The area wise collection representing the total number of individuals collected is summarized in Table 1. This included 11 species of the subfamily Eumeninae, 8 of Polistinae and 5 of Vespinae. At taxonomic level, Polistinae was the most abundant with a relative abundance of $65 \%$ followed by Vespinae $33 \%$ while the least abundant subfamily observed (2\%) was Eumeninae (Table 2). At the species level $P$. stigma had a relative abundance of $28 \%$ in the family followed by Vespula flaviceps $(20 \%)$ and P. olivaceous (14\%).

Polistinae was the dominant subfamily in six locations represented by eight species and two genera in a set of 1548 specimens from the area. The genus Polistes is widely distributed while Ropalidia was present only in Kabal and Barikot. Out of the Polistes species, $P$. olivaceous, $P$. wattii and $P$. flavus were collected from all the locations except Bahrain. $P$. rothneyi was collected from five locations and P. stigma from two locations, i.e., Kabal and Khwaza Khela. Of the two species of Ropalidia, $R$. cyathiformis was collected in Kabal while $R$. brevata from Barikot. Vespinae were widely distributed in the study area and 798 specimens of the subfamily were collected from all the seven locations. The subfamily is represented in the area by five species; four in the genus Vespa and one in the genus Vespula. Vespa velutina was found to be the most common hornet of the study area and was collected from all the locations. According to the bee keepers of the area, this hornet is a voracious predator of the bee and hence poses great threat to the apiculture. The second common hornet was the Vespa tropica which was collected from six locations, Vespa orientalis was collected from Babozai and Barikot while Vespa mandarinia was only collected from Matta. In the area, only one species of the yellow jacket, Vespula flaviceps, is present and it was only collected from Kabal. A total 
Table 1 Location wise collection of wasps.

\begin{tabular}{|c|c|c|c|c|c|c|c|c|}
\hline Species & Kabal & Babozai & Matta & Barikot & Charbagh & Khwaza Khela & Bahrain & Total \\
\hline Vespa velutina & 139 & 60 & 31 & 25 & 13 & 14 & 9 & 291 \\
\hline Vespa tropica & 15 & 5 & 1 & 4 & 1 & 1 & - & 27 \\
\hline Vespa orientalis & - & 5 & - & 4 & - & - & - & 9 \\
\hline Vespa mandarinia & - & - & 1 & - & - & - & - & 1 \\
\hline Vespula flaviceps & 470 & - & - & - & - & - & - & 470 \\
\hline Polistes rothneyi & 47 & 12 & 2 & 1 & - & 3 & - & 65 \\
\hline P. stigma & 625 & - & - & - & - & 66 & - & 691 \\
\hline P. olivaceous & 176 & 69 & 14 & 62 & 3 & 10 & - & 334 \\
\hline P. flavus & 142 & 42 & 10 & 37 & 2 & 9 & - & 242 \\
\hline P. wattii & 80 & 29 & 14 & 26 & 2 & 8 & - & 159 \\
\hline P. indicus & 29 & 9 & - & 7 & - & - & - & 45 \\
\hline Ropalidia cyathiformis & 10 & - & - & - & - & - & - & 10 \\
\hline Ropalidia brevata & - & - & - & 2 & - & - & - & 2 \\
\hline Antepipona deflenda & 1 & - & - & - & - & - & - & 1 \\
\hline Antepipona sibilans & 1 & - & - & - & - & - & - & 1 \\
\hline Rhynchium spp 1 & 1 & - & - & 1 & - & - & - & 2 \\
\hline Rhynchium spp 2 & 1 & - & - & - & - & - & - & 1 \\
\hline Rhynchium spp 3 & 1 & - & - & - & - & - & - & 1 \\
\hline Rhynchium bruneum & 5 & 4 & - & - & - & - & - & 9 \\
\hline Rhynchium quinquecinctum & 11 & 6 & - & - & - & - & - & 17 \\
\hline Rhynchium carnaticum & - & 1 & - & - & - & - & - & 1 \\
\hline Antodynerus flavescens & 5 & - & 2 & 2 & - & - & - & 9 \\
\hline Delta dimidiatepenne & 4 & 1 & - & 2 & - & - & - & 7 \\
\hline D. esuriens & - & - & - & 2 & - & - & - & 2 \\
\hline Total & 1763 & 243 & 75 & 175 & 21 & 111 & 9 & 2397 \\
\hline
\end{tabular}

of 51 individuals representing 11 species under four genera of the subfamily Eumeninae were collected. Although the least abundant but most species rich, the Eumeninae is not evenly distributed among the seven locations. The members of the Eumeninae were only collected from Kabal, Babozai, Matta, and Barikot. Four species, Antepipona deflenda, A. sibilans and two unidentified species of the genus Rhynchium were only collected from Kabal, one species Rhynchium carnaticum from Babozai, one species $D$. esuriens from Barikot while the rest were shared by Kabal, Barikot and Matta or Babozai.

The Simpson index of diversity (1-D) value for the Eumeninae is 0.803 while those for Vespinae and Polistinae are 0.519 and 0.717 , respectively. The values of Menhinick and Margalef indices are also highest for the Eumeninae as compared to Vespinae and Polistinae. The comparison in terms of richness and diversity is shown in Fig. 1.

From Tehsil Kabal, a total of 1763 specimens were collected representing 19 species under 8 genera of the 3 subfamilies and hence is the most diverse among the 7 tehsils. Of the total 19 species collected from Kabal, 13 are shared with other

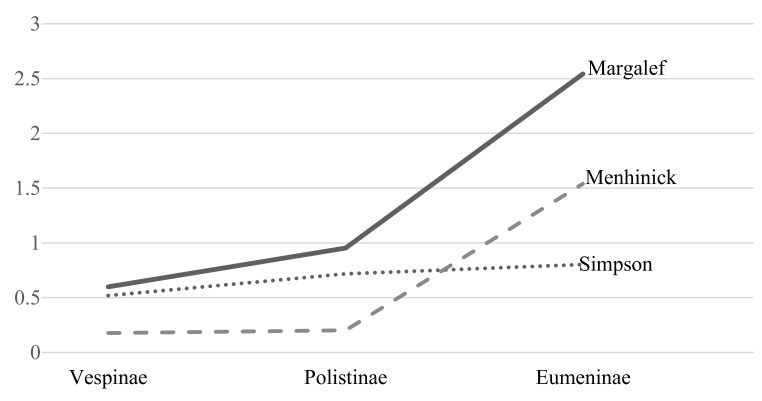

Fig. 1 Margalef, Simpson (1-D) and Menhinick indices for the 3 subfamilies of Vespidae.

locations and 6 are collected only from Kabal. From Babozai, 12 species were collected, in which $R$. carnaticum was only collected from this location. From Matta 8 species, Barikot 13 species, Charbagh 5 species, Khwaza Kheka 7 species and Bahrain, one species was collected (Table 1).

The data show that Kabal is the most diverse locality with a Simpson (1-D) value of 0.77 showing $77 \%$ diversity. Kabal was also found to be the most species rich, the value of Margalef index for the whole study area, i.e., Swat is 2.956, while the 
Table 2 Relative abundance $R_{\mathrm{A}}$ of the species with in their own subfamilies and within the family.

\begin{tabular}{|c|c|c|c|c|}
\hline \multirow[t]{2}{*}{ Subfamily } & \multirow[t]{2}{*}{ Species } & \multirow[t]{2}{*}{$n_{i}$} & \multicolumn{2}{|c|}{$R_{\mathrm{A}}$} \\
\hline & & & Subfamily & Family \\
\hline \multirow{8}{*}{$\begin{array}{l}\text { Polistinae } \\
(N=1548)\end{array}$} & P. olivaceous & 334 & 0.216 & 0.139 \\
\hline & P. wattii & 159 & 0.103 & 0.066 \\
\hline & P. flavus & 242 & 0.156 & 0.102 \\
\hline & $P$. indicus & 45 & 0.029 & 0.018 \\
\hline & P. rothneyi & 65 & 0.042 & 0.027 \\
\hline & P. stigma & 691 & 0.446 & 0.288 \\
\hline & R. brevata & 2 & 0.002 & 0.001 \\
\hline & R. cyathiformis & 10 & 0.006 & 0.004 \\
\hline \multirow{5}{*}{$\begin{array}{l}\text { Vespinae } \\
(N=798)\end{array}$} & V. velutina & 291 & 0.365 & 0.121 \\
\hline & V. tropica & 27 & 0.034 & 0.011 \\
\hline & $V$. orientalis & 9 & 0.011 & 0.004 \\
\hline & V. mandarinia & 1 & 0.001 & 0.0004 \\
\hline & V. flaviceps & 470 & 0.589 & 0.196 \\
\hline \multirow{10}{*}{$\begin{array}{l}\text { Eumeninae } \\
(N=51)\end{array}$} & A. deflenda & 1 & 0.019 & 0.0004 \\
\hline & A. sibilans & 1 & 0.019 & 0.0004 \\
\hline & A. flavescens & 9 & 0.176 & 0.004 \\
\hline & D. dimidiatepenne & 7 & 0.137 & 0.003 \\
\hline & D. esuriens & 2 & 0.039 & 0.001 \\
\hline & R. bruneum & 9 & 0.176 & 0.004 \\
\hline & R. carnaticum & 1 & 0.019 & 0.0004 \\
\hline & R. unidentified & 2 & 0.039 & 0.001 \\
\hline & R. quinquecinctum & 17 & 0.333 & 0.007 \\
\hline & R. unknown & 2 & 0.039 & 0.001 \\
\hline
\end{tabular}

Table 3 Diversity of the district Swat and its seven tehsils using Margalef, Simpson (1-D), and Menhinick diversity indices.

\begin{tabular}{lrccc}
\hline Location & $N$ & Margalef & Simpson & Menhinick \\
\hline Swat & 2397 & 2.956 & 0.828 & 0.490 \\
Kabal & 1763 & 2.408 & 0.777 & 0.514 \\
Babozai & 243 & 2.003 & 0.744 & 0.770 \\
Matta & 75 & 1.621 & 0.739 & 0.924 \\
Barikot & 175 & 2.147 & 0.767 & 0.983 \\
Charbagh & 21 & 1.314 & 0.576 & 1.091 \\
Khwaza K. & 111 & 1.274 & 0.610 & 0.664 \\
Bahrain & 9 & 0 & 0 & 0.333 \\
\hline
\end{tabular}

highest value is 2.408, among the 7 tehsils of Kabal. The Margalef, Simpson (1-D) and Menhinick values for Babozai were $2.00,0.74$, and 0.77 , respectively. From Bahrain only nine specimens of one species, Vespa velutina, were collected representing zero diversity. Margalef, Simpson (1-D) and Menhinick values for Bahrain are 0,0 , and 0.33 , respectively (Table 3).

\section{DISCUSSION}

This study was the first attempt to find out the diversity of Vespidae in the area. Various faunistic works on the Vespidae of Pakistan are available ${ }^{21}$ but the present study explores the diversity among species of Vespidae with application of various diversity indices. A total of 24 species were identified from a sample size of 2397 individuals. It is necessary to identify and count the individuals properly up to species level for ecological purposes ${ }^{22}$. However, species quantification is difficult ${ }^{23}$ but can be estimated using statistical tools such as species abundance distributions ${ }^{11}$. It was observed that the subfamily Eumeninae was the most diverse and species rich subfamily while the least diverse was the Vespinae. On the other hand, Polistinae was found to be the most abundant and dominant subfamily. The species diversity uses mathematical indices called diversity indices using information on evenness and richness ${ }^{24}$. It is useful to identify insects and to group them in accordance with their environment, climate, host, prey, and predators ${ }^{9}$. According to the feeding behaviour, it was observed that majority of the members of the Vespidae were carnivorous, though some also feed on plants or nectar. It is observed globally that herbivorous insects are more common than carnivorous ${ }^{25}$. Keeping in view the agricultural importance, the Vespidae plays a key role in pollination by visiting various flowers for nectar and insects and biological control by feeding the insects and their larvae ${ }^{26}$. Results reveal that numerically, Polistinae was the dominant and agronomically most important, as it was widely distributed in the area. According to Ref. 27, members of the Hymenoptera form major portion of the insect community and play vital role of agricultural importance.

The climate, landscape and agriculture of the area had a great effect on species richness and diversity $^{27}$. The diversity and species richness observed in seven locations were different from each other. The most species rich and diverse locality was Kabal while the least diverse locality was Bahrain. District Swat falls in Sino Japanese region with characteristic vegetation including coniferous forests, open woodlands and rarely scrubs ${ }^{28}$. All the seven locations differ from each other in climate, physical features and vegetation. The study reveals that species richness variations are affected more by border effects than climatic factors. Of course no one community has the same biodiversity as the other even if both are having the same characters like 
topography, vegetation and weather ${ }^{29}$. Although Kabal was the most species rich as calculated by Simpson and Menhinick indices but low evenness. A community with the low evenness is that where a few species dominate ${ }^{30}$. In all the sites except Bahrain, the wasps were dominated by Polistinae.

\section{CONCLUSIONS}

The study shows that the subfamily Eumeninae was the least abundant but most diverse and species rich. Only 51 specimens out of a total of 2397 belonged to this subfamily represented by 4 genera and 11 species. The most dominant subfamily was the Polistinae, second in terms of diversity and species richness. About 1548 specimens representing 2 genera and 8 species belong to the subfamily Polistinae. Second in terms of dominance and third in terms of species richness and diversity was the Vespinae having 798 specimens represented by 2 genera and 5 species. The study reflects that the area has a great potential and needs further exploration.

Acknowledgements: The Authors are thankful to the following staff of Govt: Degree College Kabal Swat, Prof. Fazli Rahman, Statistics Department, Mr Shamsher Ali and Mr Izhar Ali of Zoology Department for their help in the collection of wasps and statistical Analysis.

\section{REFERENCES}

1. Pickett KM, Carpenter JM (2010) Simultaneous analysis and the origin of eusociality in the Vespidae (Insecta: Hymenoptera). Arthropod Syst Phylogeny 68, 3-33.

2. Mahmood K, Mishkatullah, Aziz A, Hassan SA, Innayatullah M (2012) To the knowledge of Vespidae (Hymenoptera) of Pakistan. Zootaxa 3318, 26-50.

3. Suhs RB, Somavilla A, Putzke J, Köhler A (2009) Pollen vector wasps (Hymenoptera, Vespidae) of Schinus terebinthifolius Raddi (Anacardiaceae), Santa Cruz do Sul, RS, Brasil. Rev Bras Biocienc 7, 138-43.

4. Pannure A, Belavadi VV, Carpenter JM (2016) Taxonomic studies on potter wasps (Hymenoptera: Vespidae: Eumeninae) of south India. Zootaxa 4171, $1-50$.

5. Archer ME (2012) Vespine Wasps of the World: Behaviour, Ecology \& Taxonomy of the Vespinae, Siri Scientific Press, Manchester, UK.

6. Fateryga AV (2010) Trophic relations between vespid wasps (Hymenoptera, Vespidae) and flowering plants in the Crimea. Entomol Rev 90, 698-705.

7. Muller UR (1990) Insect Sting Allergy: Clinical Picture, Diagnosis and Treatment, Gustav Fischer Verlag, Stuttgart, Germany.
8. Warpinski JR, Bush RK (1990) Stinging insect allergy. $J$ Wilderness Med 1, 249-57

9. Speight MR, Hunter MD, Watt AD (2008) Ecology of Insects: Concepts and Applications, 2nd edn, WileyBlackwell, Singapore.

10. Longino JT, Colwell RK (1997) Biodiversity assessment using structured inventory: capturing the ant fauna of a tropical rain forest. Ecol Appl 7, 1263-77.

11. Chao A, Colwell RK, Lin CW, Gotelli NJ (2009) Sufficient sampling for asymptotic minimum species richness estimators. Ecology 90, 1125-33.

12. Colwell RK, Coddington JA (1994) Estimating terrestrial biodiversity through extrapolation. Philos Trans $R$ Soc Lond B Biol Sci 345, 101-18.

13. Inam UR, Alian MV (2002) Swat: An Afghan Society in Pakistan, City Press, Islamabad.

14. Population Census Organization (2008) District Census Report of Swat, Statistics Division, Govt: of Pakistan, Islamabad.

15. Dvorak L, Carpenter JM (2010) New records of vespid wasps from Yemen with synonymy in $\mathrm{Be}$ lonogaster (Hymenoptera: Vespidae: Polistinae and Eumeninae). Linz Biol Beitr 42, 561-3.

16. Carpenter JM, Gusenleitner J, Madl M (2009) A catalogue of the Eumeninae (Hymenoptera: Vespidae) of the Ethiopian region excluding Malagasy subregion. Linz Biol Beitr 41, 513-638.

17. Ebrahimi E, Carpenter JM (2008) Catalogue of the vespid wasps of Iran (Hymenoptera, Vespidae). Zootaxa 1785, 1-42.

18. Margalef R (1969) Perspective in Ecological Theory, University of Chicago Press, Chicago, pp 111.

19. Menhinick EF (1964) A comparison of some speciesindividuals diversity indices applied to samples of field insects. Ecology 45, 859-61.

20. Simpson EH (1949) Measurement of diversity. Nature 163, 688.

21. Rafi MA, Carpenter JM, Qasim M, Shehzad A, Zia A, Khan MR, Mastoi MI, Naz F, et al (2017) The vespid fauna of Pakistan. Zootaxa 4362, 1-28.

22. Gotelli NJ (2004) A taxonomic wish-list for community ecology. Philos Trans R Soc Lond B Biol Sci 359, 585-97.

23. Longino JT, Coddington J, Colwell RK (2002) The ant fauna of a tropical rain forest: estimating species richness three different ways. Ecology 83, 689-702.

24. Schowalter TD (2006) Community structure. In: Insect Ecology, 2nd edn, Academic Press, San Diego, CA, pp 251-82.

25. Strong DR, Lawton JH, Southwood SR (1984) Insects on Plants: Community Patterns and Mechanisms, Harvard University Press, Cambridge.

26. Chown SL, Hoffmann AA, Kristensen TN, Angilletta MJ, Stenseth NC, Pertoldi C (2010) Adapting to climate change: a perspective from evolutionary physiology. Climate Res 43, 3-15.

27. Mokam DG, Djieto-Lordon CD, Bilong CB (2014) 
Patterns of species richness and diversity of insects associated with cucurbit fruits in the southern part of Cameroon. J Insect Sci 14, 1-9.

28. Ali A, Badshah L, Hussain F, Shinwar ZK (2016) Floristic composition and ecological characteristics of plants of Chail valley, district Swat, Pakistan. Pak $J$ Bot 48, 1013-26.

29. Kim KC (2017) Taxonomy and management of insect biodiversity. In: Foottit RG, Adler PH (eds) Insect Biodiversity: Science and Society, 2nd edn, John Wiley \& Sons, pp 767-82.

30. Magurran AE (1988) Diversity indices and species abundance models. In: Ecological Diversity and Its Measurement, Springer, Dordrecht, pp 7-45. 